\title{
Donor HLA Genotyping using Polymerase Chain Reaction- Sequence Specific Primers (PCR-SSP) as Method for Acquiring Donor Panel in Platelet Refractoriness
}

\author{
Tubagus Djumhana Atmakusuma ${ }^{1}$, Andhika Rachman ${ }^{1}$, Ni Ken Ritchie² \\ ${ }^{1}$ Division of Hematology-Medical Oncology, Department of Internal Medicine Dr. Cipto Mangunkusumo General Hospital/ \\ Faculty of Medicine Universitas Indonesia, Jakarta, Indonesia \\ ${ }^{2}$ Regional Blood Transfusion Unit, Indonesian Red Cross, Jakarta, Indonesia
}

Background: Evaluation and identification of HLA antibodies in the recipient's serum is of utmost importance prior to transplantation and transfusion. HLA typing is a steppingstone in proposing a donor panel. In order to obtain the HLA typing, Polymerase Chain Reaction-Sequence Specific Primers (PCR-SSP) can be performed.

Materials and method: This is a preliminary study to determine HLA polymorphism by HLA genotyping in 43 blood donors. DNA from the samples was isolated using commercial kits according to the standard protocol. The DNA then was amplified using PCR-SSP methods and analyzed using the provided set in the kit.

Results: This study found that the most frequent HLA-A alleles was HLA-A*24 (41.9\%). For HLA-B alleles, the most common was HLA-B*15 (28\%). Most frequent HLA-A-B haplotypes was HLA-A*24-B*15 (11.3\%). The results from this study concurs with that of previous study. However, some alleles might vary due to difference in study population. Determining HLAtyping is of paramount importance in an ethnically diverse country such as Indonesia. In contrast to homogenous caucassian country, difference in ethnicity might cause platelet refractoriness due to incompatibility. HLA-typing would also guide the diagnostic workup and required treatment strategy for platelet refractoriness.

Conclusion: From the HLA typing using PCR-SSP in blood donors in Jakarta, we found that the most frequent alleles were HLA-A*24 and HLA-B*15; and the most frequent haplotypes were HLA-A*24-B*15. This study should be upscaled to include larger population and ethnic groups to obtain complete profile of Indonesian population.

Keywords: platelet refractoriness, HLA, donor, PCR-SSP, transfusion medicine

\section{Introduction}

Human Leukocyte Antigen (HLA) is a surface antigen expressed on human cells. It is a biologic product coded by a group of HLA genes which are linked to each other composing a structure called Major Histocompatibility Complex (MHC). ${ }^{1}$ HLA class I molecules can be found on nucleated cells and platelets. Therefore, every time a patient receives platelet transfusion, there is considerable risk of immunologic reaction against HLA class I molecules. ${ }^{2}$ The

Date of submission: April 21, 2021

Last Revised: September 23, 2021

Accepted for publication: September 24, 2021

Corresponding Author:

Tubagus Djumhana Atmakusuma

Division of Hematology-Medical Oncology, Department of Internal Medicine

Dr. Cipto Mangunkusumo General Hospital/Faculty of Medicine Universitas Indonesia

Jl. Diponegoro No. 71, Jakarta, Indonesia

e-mail: hom_fkui@yahoo.com

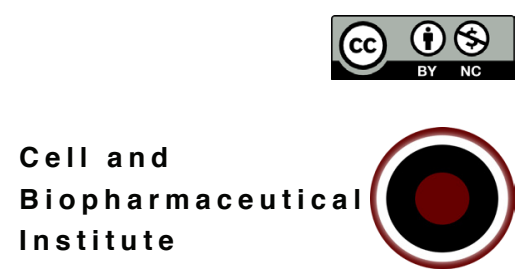


antibodies acquired by the recipient with history of multiple platelet transfusions are antibodies against HLA class I (80\%) and HPA antibodies (20\%). ${ }^{3}$ The reaction between transfused platelets and patient's antibody which causes failure to reach platelet increment is defined as platelet refractoriness. ${ }^{2}$

Platelet transfusions ranked second in blood transfusion requests in the Blood Bank Service of Jakarta, Indonesia. The largest "consumer" is the hematologyoncology patients of The Division of Hematology-Medical Oncology, Department of Internal Medicine Dr. Cipto Mangunkusumo General Hospital/ Faculty of Medicine Universitas Indonesia. ${ }^{4}$ Previous study in The Dharmais National Cancer Centre showed that patients receiving either multiple-donor platelet units or single donor unit (apheresis) will experience platelet refractoriness. ${ }^{5}$ The antibodies detected in hematology-oncology patients in 2007 in Dr. Cipto Mangunkusumo General Hospital were against HLA class I (38.9\%) and GP IIb/IIIa epitope (2.8\%). That study also reported transfusion failure in patients with antibodies detected by enzyme-linked immunosorbent assay (ELISA) method. ${ }^{6}$

The advances in HLA in Indonesia were pioneered since the 1970s. However, the reagent to perform the serological testing (ELISA) is still imported from overseas. Although ELISA has better sensitivity to determine antibody specificity, the gold standard is microlymphocytotoxicity test. $^{7}$ The microlymphocytotoxicity test can be routinely performed if known-phenotype donor cell panels are readily available. ${ }^{8}$ Evaluation and identification of HLA antibodies in the recipient's serum is of utmost importance prior to transplantation and transfusion. There is no prior knowledge of the genotype of donor HLA as the basis for compiling a panel that will be used in microlymphocytotoxicity to detect antibodies to HLA in cases of platelet refractoriness. Therefore, HLA typing is a steppingstone in proposing a donor panel. In addition, this preliminary study aimed to provide determine the HLA polymorphism between blood donors in the Blood Bank of Jakarta, despite wide ethnic diversity, as part of the strategy to overcome platelet refractoriness.

In order to obtain the HLA typing, Polymerase Chain Reaction-Sequence Specific Primers (PCR-SSP) can be performed. This method has been proved successful in class I HLA including HLA-A, HLA-B, HLA-C, HLA-DRB, and class II HLA genes. ${ }^{9}$

\section{Materials and methods}

This is a preliminary study to determine HLA polymorphism by HLA genotyping in 43 blood donors in the Blood Bank of Jakarta. This study aims to obtain donor panel for management of platelet refractoriness. The subjects were interviewed to get accurate ethnicity data from three generations and beyond.

This study is done in accordance of Declaration of Helsinki. Appropriate consent was obtained from all the subjects. Proper ethical clearance was acquired and reviewed by the Ethics Committee of The Faculty of Medicine, University of Indonesia (No. 460/H2.F1/ETIK/2013).

\section{Data Collection}

Three milliliters of whole blood were obtained from the apheresis donor in the blood bank. Sample analysis was done in the molecular biology laboratory of The Division of Hematology-Medical Oncology, Department of Internal Medicine Dr. Cipto Mangunkusumo General Hospital/ Faculty of Medicine Universitas Indonesia.

DNA from the samples was isolated using Geneaid ${ }^{\mathrm{TM}}$ DNA Isolation kit from Geneaid Biotech Ltd, New Taipei City, Taiwan according to the standard protocol. The resulted DNA then was eluted using sterile aquabidest solution or eluate buffer which contains EDTA. Measurement of DNA quantity is performed by measuring absorbance at $260 \mathrm{~nm}$ wavelength. Purity was measured at $280 \mathrm{~nm}$ wavelength. DNA quality and quantity were analyzed using $0.9 \%$ agarose gel electrophoresis. DNA bands which were thick and close to the well is considered sufficient. After obtaining sufficient quality, DNA was amplified using Morgan ${ }^{\mathrm{TM}}$ HLA SSP Kit from Texas Biogene Inc, Texas, USA, with PCRSSP methods and thermal cycler apparatus as detailed in the provided protocol inside the kit. After amplification, positive DNA bands were identified by $2 \%$ agarose gel electrophoresis. The results were analyzed using the software provided in the kit.

\section{Results}

The Blood Bank of Jakarta, which is located in the capital, acquired blood donors from various ethnicity. Majority of the donor's ethnicity were Javanese $(55.8 \%)$, Sundanese (14\%), Betawi (11.6\%), mixture of Betawi-Banjar (9.3\%), Bataknese (2.3\%), Chinese (2.3\%), Betawi-Javanese $(2.3 \%)$, and Javanese-Manadonese (2.3\%). 


\section{Frequency of HLA-A Alleles}

Estimated frequency of HLA-A alleles in this preliminary study is depicted in Table 1 . There are 11 alleles, with four most frequent were HLA-A*24 (41.9\%), - $\mathrm{A} * 02(23.2 \%)$, $-A * 11(16.3 \%)$ and $-A * 33(8.1 \%)$. Twenty-one percent of the samples were estimated to be homozygote, i.e., HLA-A*24,24 (19\%) and $-A * 11,11(2 \%)$.

\section{Frequency of HLA-B Alleles}

HLA-B alleles are more variable than HLA-A. In this study, there were 17 HLA-B alleles (Table 2). Four most frequent HLA-B alleles are HLA-B*15 (28\%), -B*35 (12\%), -B*18 $(10 \%)$, and $-B^{*} 38(10 \%)$. Only $7 \%$ were homozygotes, i.e., HLA-B*15,15 (5\%) and -B*38,38 (2\%).

\section{HLA Haplotype Frequency}

HLA-A-B Haplotypes acquired from this preliminary study, as shown in Table 3, were those with frequency $>2 \%$. Four most frequent HLA-A-B haplotypes were HLA-A*24-B*15 $(11.3 \%),-\mathrm{A} * 24-\mathrm{B} * 35(8.3 \%)-\mathrm{A} * 02-\mathrm{B} * 15(7.1 \%)$, and $-\mathrm{A} * 24-\mathrm{B} * 38(5.4 \%)$.

\section{Discussion}

This preliminary study, which utilized low-resolution DNA typing method, acquired 11 HLA-A alleles and 17 HLA-B alleles from 8 ethnicities, i.e., Javanese, Betawi, Sundanese, Bataknese, Chinese, Betawi-Javanese, Betawi-Banjar, and Javanese-Manadonese.

The results obtained from this preliminary study concurs with previous study in Indonesia ${ }^{10}$, which founded that the most frequent is HLA-A*24, followed by HLA-A*02, $-A^{*} 11$ and $-A^{*} 33$. Thus, matching was probably due to the same racial profile of the subjects of this study with the previous study. Our subjects consisted of $55.8 \%$ Javanese and $14 \%$ Sundanese, while the previous study consisted of $15.2 \%$ Javanese and $84.8 \%$ Sundanese. These frequent HLA-A alleles were also found in a study in German population with the exception of $-A^{*} 33$ is less frequent than $-A * 26$ and $A * 29 .{ }^{11}$ The comparison of HLA-A frequencies between Indonesian and German population is depicted in Table 4.

There was other allele in this study, HLA-A*68, that was not found in the previous study. This might be caused by the Sundanese-dominant nature of the previous study subjects. On the contrary, $1.24 \%$ HLA-A*30 and $0.5 \%$
$-A^{*} 32$ in Sundanese subjects of the previous study were not found in ours since our Sundanese subjects only comprised $14 \%$ of the subjects. Hence, the probability of finding those alleles is as low as $0.17 \%$ and $0.07 \%$, respectively. Compared to the Germans, Indonesia people has HLA-A*74 exclusively (Table 4). ${ }^{10,11}$

For the HLA-B, the most frequent were HLA-B*15, $-B * 35$ dan $-B * 18$, just the same as the results of the previous Indonesian study. ${ }^{10}$ In Javanese and Betawi population, we acquired newly found alleles: HLA $-\mathrm{B}^{*} 55$ and $-\mathrm{B} * 78$. The HLA-B*78 allele is also absent in The Germans. The comparison of HLA-B allele between Indonesian and German population can be seen on Table 5. On the contrary, there are several alleles which were not found in this study, i.e., HLA-B*37,-B*39,-B*41, and -B*48 with the frequency of $0.25 \%, 1.39 \%, 0.25 \%$, and $0.25 \%$, respectively in Sundanese population, except for $-\mathrm{B} * 39$ with the probability of obtaining it by $0.035 \%$.

For the HLA-A-B haplotypes, the two most frequent were HLA-A*24-B*15 and $-A * 24-B * 35$. HLA-A*34-B*15 and $A * 33-B * 44$ since $-A * 33$ and $-A * 34$ is commonly found in Sundanese population with $15.61 \%$ and $6.96 \%$ frequency, respectively. ${ }^{10}$ In this study, those frequencies were only $8.14 \%$ and $2.33 \%$ because our Sundanese population is only one-sixth of those in previous study.

A preliminary study in 2009 took samples from patients with multiple platelet transfusion which required transfusions from the Red Cross of Jakarta. They used German population panel, and obtained the presence of multiantibodies, with the most frequent being HLA-A*02 antibody. ${ }^{12}$

If the most prevalent antibody is against HLA-A*02 and the most frequent HLA-A allele is $-\mathrm{A}^{*} 24$, it would be very difficult to obtain an HLA-matched product due to the cross-reactivity between HLA-A*02 and $-A * 24$. Therefore, a new strategy has to be formulated for patients with platelet multitransfusion in the blood bank of Jakarta.

Reflecting on the difference of allele frequencies between Indonesian and German population in this study, it is estimated that there are also other antibodies which were undetected since we used the German population's panel. Therefore, the platelet antibody testing should be performed using Indonesian population's panel.

The importance of HLA-typing in the case of platelet refractoriness has been discussed in several publications. In platelet refractory patients, the most important step 


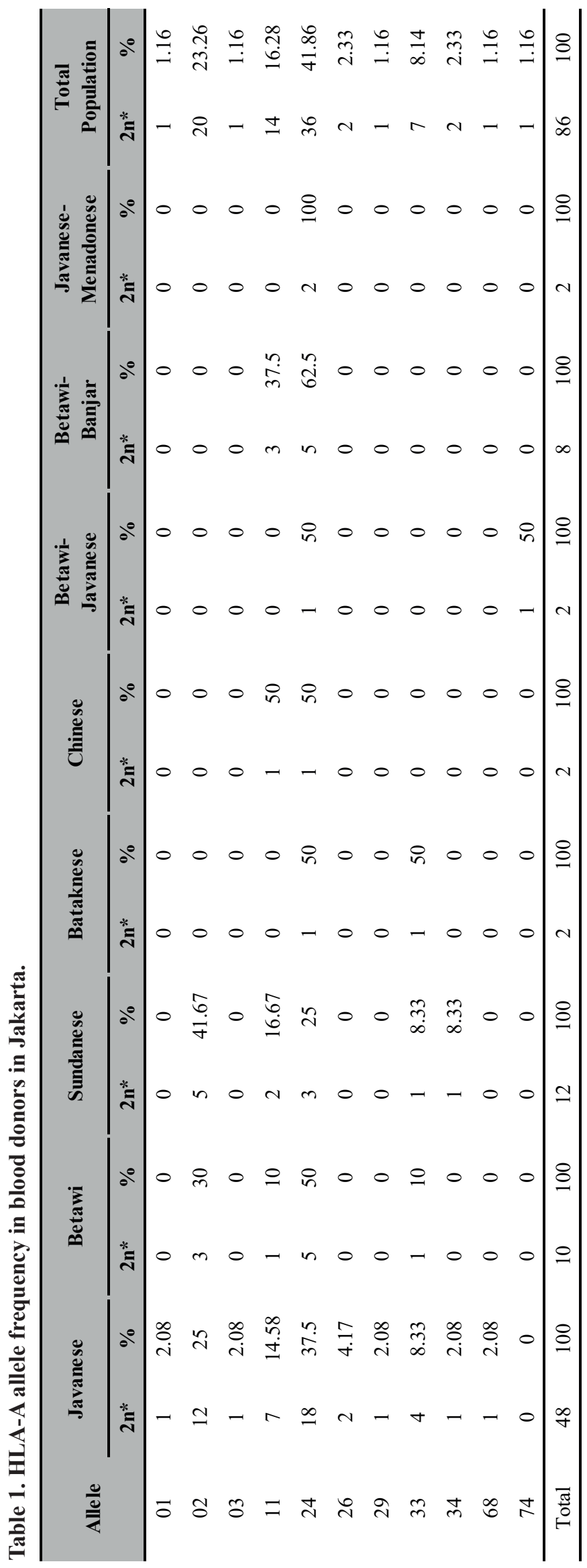




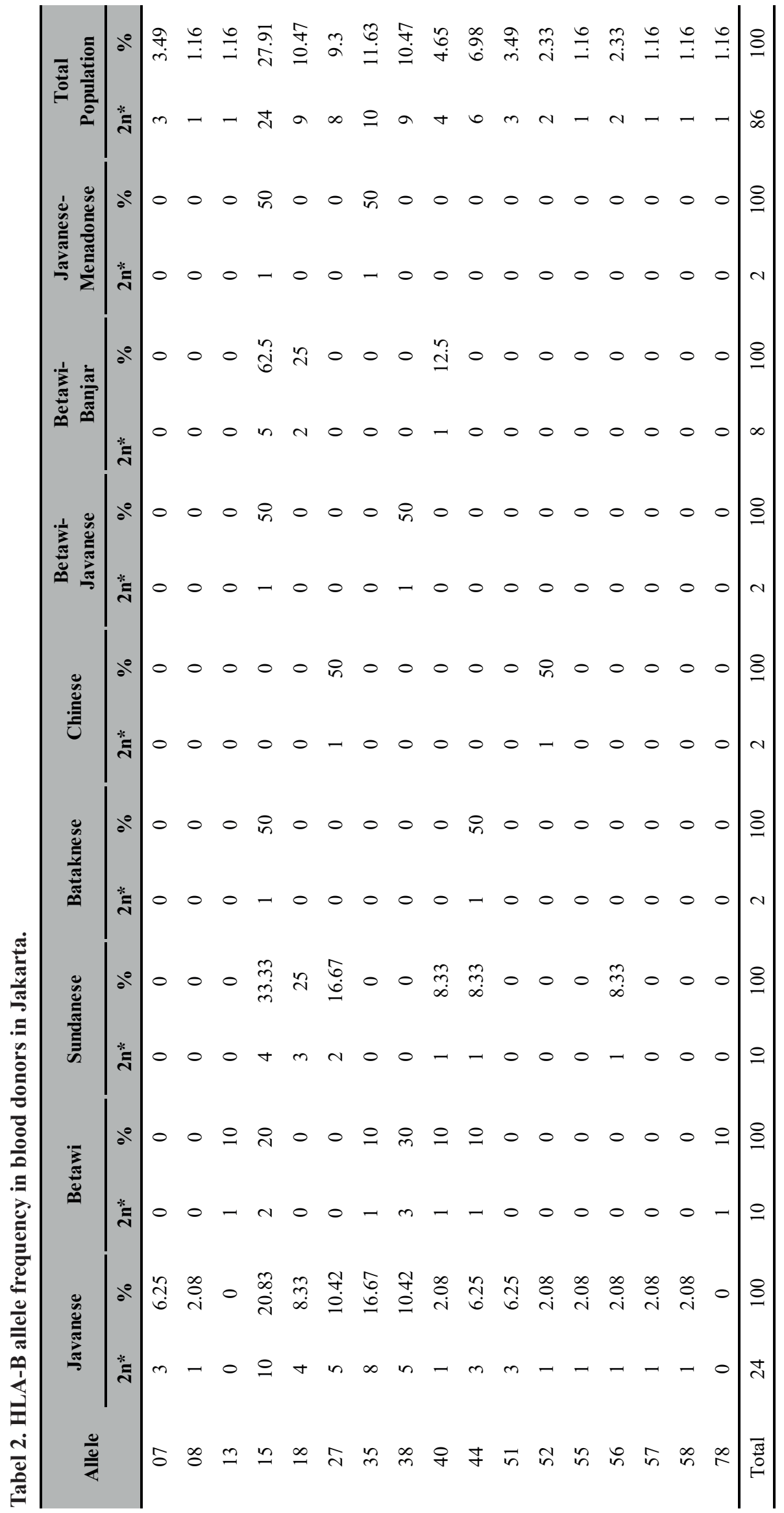


Table 3. The most frequent HLA-A-B haplotype in the blood donors in PMI Jakarta.

\begin{tabular}{cc}
\hline Haplotype HLA-A-B & Frequency (\%) \\
\hline $\mathrm{A} * 24 \mathrm{~B} * 15$ & 11.3 \\
$\mathrm{~A} * 24 \mathrm{~B} * 35$ & 8.3 \\
$\mathrm{~A} * 02 \mathrm{~B} * 15$ & 7.1 \\
$\mathrm{~A} * 24 \mathrm{~B} * 38$ & 5.4 \\
$\mathrm{~A} * 24 \mathrm{~B} * 18$ & 4.8 \\
$\mathrm{~A} * 11 \mathrm{~B} * 15$ & 4.8 \\
$\mathrm{~A} * 22 \mathrm{~B} * 27$ & 3.6 \\
$\mathrm{~A} * 24 \mathrm{~B} * 27$ & 3.0 \\
$\mathrm{~A} * 33 \mathrm{~B} * 44$ & 3.0 \\
$\mathrm{~A} * 11 \mathrm{~B} * 27$ & 2.4 \\
$\mathrm{~A} * 33 \mathrm{~B} * 15$ & 2.4 \\
$\mathrm{~A} * 02 \mathrm{~B} * 35$ & 2.4 \\
\hline
\end{tabular}

is to identify donors with complete HLA-A and HLA-B matching. ${ }^{13}$ HLA-matched platelet transfusion has been proved to increase the corrected count increment significantly compare to random donors. ${ }^{14}$ Therefore, obtaining a proper HLA typing is paramount. Obtaining proper match not only will benefit the patient clinically, but it will also save treatment cost. ${ }^{15}$

Although not routinely done in Indonesia, HLA-typing is recommended American transfusion guidelines. ${ }^{16}$ It would guide the next diagnostic workup and required treatment strategy. In addition, implementation of HLA typing is a stepping stone before proceeding to more sophisticated matching, such as human platelet antigen (HPA) matching. ${ }^{16}$

This study is an important pilot to a nationwide study since Indonesia has vast population diversity. In a homogenous country, HLA typing might not be that crucial. However, studies in ethnic diverse donor population showed that HLA-typing should be done especially in the case of platelet refractoriness. ${ }^{17}$ For example, non-caucasion donors in the Netherlands are suggested to be HLA-typed to prevent platelet refractoriness. Therefore, we need HLAtyping in Indonesia due to this diverse ethnicity in the donor pool.

\section{Conclusion}

From the HLA typing using Polymerase Chain ReactionSequence Specific Primers (PCR-SSP) in blood donors in the Jakarta Red Cross, we found that the most frequent alleles were HLA-A*24 and HLA-B*15; and the most frequent haplotypes were HLA-A*24-B*15. This study

Table 4. HLA-A allele frequency in Indonesian and Germans.

\begin{tabular}{cccc}
\hline \multirow{2}{*}{ Allele } & \multicolumn{2}{c}{ Indonesians } & Germans \\
\cline { 2 - 4 } & $\mathbf{n}=\mathbf{4 3 *}$ & $\mathbf{n}=\mathbf{4 7 4 * *}$ & $\mathbf{n}=\mathbf{1 4 . 8 3 5 * * *}$ \\
\hline 24 & 0.42 & 0.3756 & 0.0955 \\
02 & 0.23 & 0.1477 & 0.2916 \\
11 & 0.16 & 0.1624 & 0.0584 \\
33 & 0.08 & 0.1561 & 0.012 \\
29 & 0.01 & 0.0105 & 0.024 \\
74 & 0.01 & 0.0021 & - \\
26 & 0.02 & 0.0232 & 0.0397 \\
68 & 0.01 & - & 0.0057 \\
34 & 0.02 & 0.0696 & 0.0005 \\
30 & - & 0.0105 & 0.0234 \\
32 & - & 0.0042 & 0.0363 \\
\hline
\end{tabular}

*Data obtained in this study; **Ref No.10; ***Ref No.11. 
Table 5. HLA-B allele frequency in Indonesian and Germans.

\begin{tabular}{cccc}
\hline \multirow{2}{*}{ Allele } & \multicolumn{2}{c}{ Indonesians } & Germans \\
\cline { 2 - 4 } & $\mathbf{n}=\mathbf{4 3 *}$ & $\mathbf{n}=\mathbf{4 7 4 * *}$ & $\mathbf{n = 1 4 . 8 3 5 * * *}$ \\
\hline 15 & 0.3 & 0.348 & 0.0014 \\
35 & 0.14 & 0.0928 & 0.0998 \\
18 & 0.1 & 0.0802 & 0.057 \\
44 & 0.08 & 0.0886 & 0.111 \\
38 & 0.09 & 0.057 & 0.0263 \\
07 & 0.04 & 0.0337 & 0.1239 \\
27 & 0.06 & 0.0295 & 0.0485 \\
40 & 0.04 & 0.0464 & 0.0019 \\
51 & 0.04 & 0.0675 & 0.0692 \\
52 & 0.01 & 0.0105 & 0.0089 \\
55 & 0.01 & - & 0.0167 \\
58 & 0.01 & 0.057 & 0.0078 \\
57 & 0.01 & 0.0127 & 0.0344 \\
13 & 0.01 & 0.0253 & 0.0352 \\
78 & 0.01 & - & - \\
56 & 0.03 & 0.0147 & 0.0092 \\
37 & - & 0.0021 & 0.0132 \\
39 & - & 0.0021 & 0.019 \\
41 & - & 0.0021 & 0.0111 \\
48 & - & 0.0021 & 0.0001 \\
\hline
\end{tabular}

*Data obtained in this study; **Ref No.10; ***Ref No.11.

should be upscaled to include larger population and ethnic groups to obtain more complete data on HLA-typing in Indonesian population.

\section{Acknowledments}

This study has been supported by "Dana Hibah Pengembangan dan Pengelolaan Pusat Riset Universitas Indonesia" research grant in 2010. We also express our gratitude to Dr. Sentot Santoso.

\section{References}

1. S M. Mengenal antigen HLA. Jakarta: Bagian Ilmu Kesehatan Anak FK UI; 1994.

2. DM H. Modern blood banking and transfusion practices. 4th ed. Thailand: Promotion \& Service Co; 1994

3. Austen KF, Frank MM, John P. Atkinson. Samter's Immunologic Disease. 6th ed. Philadelphia: Lippincott Williams \& Wilkins: 2001.
4. Laporan tahunan Unit Transfusi Darah Daerah (UTDD) PMI Jakarta 2006.

5. Slichter SJ, Davis K, Enright H, Braine H, Gernsheimer T, Kao KJ, et al. Factors affecting posttransfusion platelet increments, platelet refractoriness, and platelet transfusion intervals in thrombocytopenic patients. Blood. 2005; 105(10): 4106-14.

6. Lubis AM, Sudoyo AW, Effendy S, Djumhana TB, Harimurti K. Hubungan antibodi anti trombosit terhadap respon transfusi trombosit pada pasien hemato-onkologi yang mendapatkan multitransfusi trombosit. Jurnal Penyakit Dalam Indonesia. 2015; 2(4): 200-7.

7. S M. Darah curah persalinan sebagai alternatif sumber antibodi HLA [Dissertation]. Jakarta: FK UI; [n.y.].

8. Mishra MN, Mani H, Narula AS, Saxena VK. HLA typing - a comparison of serology and DNA techniques. Int J Hum Genet. 2004; 4(2): 151-3.

9. Lee KO, Hong SH, Kim MJ, Park TK, Kim YJ, Lee KP. Molecular Analysis of HLA-C Using Polymerase Chain Reaction Sequence Specific Primers. J Biochem Mol Biol. 1997; 30(1): 26-32.

10. Yuliwulandari R, Kashiwase K, Nakajima H, Uddin J, Susmiarsih TP, Sofro AS, et al. Polymorphisms of HLA genes in Western Javanese (Indonesia): close affinities to Southeast Asian populations. Tissue 
Antigens. 2009; 73(1): 46-53.

11. Mueller CR, Goldmann SF, Wegener S. German normal. In: Giertsen DW, Terasaki PI. HLA. Mount Laurel: American Society for Histocompatibility and Immunogenetics; 1998. p.154-7.

12. Kiefel V, König C, Kroll H, Santoso S. Platelet alloantibodies in transfused patients. Transfusion. 2001; 41(6): 766-70.

13. Karlström C, Linjama T, Edgren G, Lauronen J, Wikman A, Höglund P. HLA-selected platelets for platelet refractory patients with HLA antibodies: a single-center experience. Transfusion. 2019; 59(3): 945-52.

14. Hyun J, Lim YM, Park KD, Han BY, Kim YH, Han KS, et al. An evaluation of platelet transfusion response using HLA crossmatch- compatible donors in patients with platelet refractoriness. Korean J Clin Lab Sci. 2009; 29(5): 481-9.

15. Juskewitch JE, Norgan AP, De Goey SR, Duellman PM, Wakefield LL, Gandhi MJ, et al. How do I ... manage the platelet transfusionrefractory patient? Transfusion. 2017; 57(12): 2828-35.

16. Fagundes IS, Franz JM, Jobim MS, Arend A, Merzoni J, Cardone $\mathrm{JM}$, et al. Diagnosis and treatment of immunological platelet refractoriness by histocompatibility. Hum Immunol. 2020; 81(5): 197-201.

17. Kreuger AL, Haasnoot GW, Somers JAE, Tomson B, van der Bon JG, van Kraaij MGJ, et al. Ensuring HLA-matched platelet support requires an ethnic diverse donor population. Transfusion. 2020; 60(5): 940-6. 